\title{
Mammary specific function of a bovine mammary epithelial cell clone cultured on collagen I coated inserts
}

\author{
H.R. McConochie, M.T. Rose', W. Haresign and B. Davies \\ Institute of Rural Sciences, University of Wales \\ Aberystwyth, Ceredigion, SY23 3AL, UK
}

\begin{abstract}
Previously we have shown that a bovine mammary epithelial cell clone isolated from lactating mammary tissue is able to differentiate morphologically and functionally on a reconstituted basement membrane. Here we show that when cultured on collagen I coated culture inserts, the presence of lactogenic hormones results in an increase in polarized secretion of $\alpha$-lactalbumin but not $\alpha$-casein. We conclude that collagen I is sufficient for milk protein gene expression and that culture insert methodology offers a practical alternative to three-dimensional culture systems when $\alpha$-lactalbumin is used as an indicator of mammary specific function.
\end{abstract}

KEY WORDS: mammary epithelial cell clone, bovine, lactogenic hormones

\section{INTRODUCTION}

The many hormones, growth factors and cell types involved in bovine mammary gland development and lactation make the elucidation of their roles difficult; a representative in vitro model of lactation would help in this regard. Previously we have isolated a mammary epithelial cell (MEC) clonal line that can undergo three-dimensional morphological and functional differentiation when cultured on a reconstituted basement membrane (McConochie et al., 2004). However, the inability to collect secretions accumulating within luminal structures restricts its usefulness as a dynamic model. The aim was to build upon these earlier observations, and to establish a model designed to promote the establishment of a polarized epithelial layer with characteristic apical secretion of proteins.

\section{MATERIAL AND METHODS}

A cloned bovine mammary epithelial cell line was isolated from mammary tissue taken from a fifth lactation Holstein cow that was $200 \mathrm{~d}$ post partum (McConochie et

\footnotetext{
${ }^{1}$ Corresponding author: e-mail: mir@aber.ac.uk
} 
al., 2004). The ability of the MEC clone to establish a polarized epithelial layer and to display functional differentiation was investigated by culturing $1.83 \times 10^{5} \mathrm{cells} / \mathrm{cm}^{2}$ on collagen I coated inserts (Becton Dickinson Lab-ware, MA, USA), in the presence of Dulbecco's modified Eagle medium (DMEM) substituted with $10 \%$ foetal bovine serum (FBS) (Invitrogen Ltd., Paisley, UK), for 24h post plating. Media was then changed to DMEM substituted with $1 \%$ FBS and either containing lactogenic hormones (PDI) (prolactin $5 \mu \mathrm{g} / \mathrm{ml}$, dexamethasone $5 \mu \mathrm{g} / \mathrm{ml}$ and insulin $5 \mu \mathrm{g} / \mathrm{ml}$; Sigma, Poole, Dorset, UK) or no lactogenic hormones (control). The experiment consisted of 4 replicates per treatment and lasted 21 days. The culture media from apical and basal compartments was changed every 3 days and stored frozen at $80^{\circ} \mathrm{C}$. Functional differentiation was evaluated by measuring the concentration of $\alpha$-lactalbumin and $\alpha$-casein in media collected from apical and basal chambers on days $0,3,6,9,12,1518$ and 21 . The concentrations of $\alpha$-lactalbumin and $\alpha$-casein were determined using sandwich ELISA that we have established. The $\alpha$-lactalbumin ELISA used a commercially available polyclonal antibody (Bethel Laboratories, Montgomery, Texas, USA); the $\alpha$-casein ELISA used a pair of monoclonal antibodies (Rose et al., 2004). Effects of treatment on total $\alpha$-lactalbumin and $\alpha$-casein concentrations, apical and basal $\alpha$-lactalbumin concentrations and proportions secreted into apical and basal compartments were analysed by one-way analysis of variance.

\section{RESULTS}

Mammary specific function was not reliant on the presence of lactogenic hormones in the cell culture media. However, the presence of lactogenic hormones had a significant stimulatory effect on both the quantity of $\alpha$-lactalbumin secreted over the 21 days of the experiment (control $=48.48 \mathrm{pg} / 10000$ cells; PDI $=202 \mathrm{pg} / 10000$ cells)

(a) Alpha casein

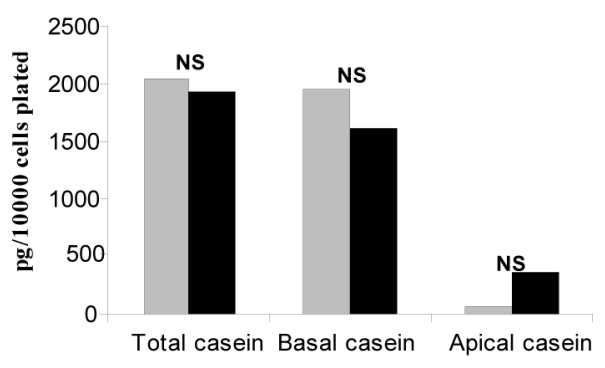

(b) Alpha Lactalbumin

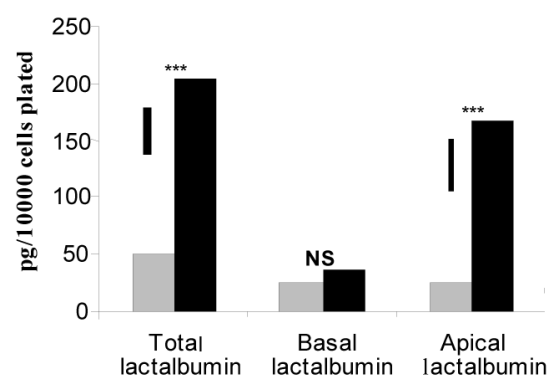

Figure 1. Effect of lactogenic hormones on total and direction of secretion of (a) alpha casein and (b) alpha lactalbumin over the 21 days of the experiment. Statistical comparisons are between no hormone addition (hatched), and prolactin, dexamethasone and insulin addition to the media (PDI; black). $* * *: \mathrm{P}<0.001$; NS: not significant. Vertical bars indicate the least significant difference 
and on the total quantity of $\alpha$-lactalbumin secreted into the apical chamber (control $=24.41 \mathrm{pg} / 10000$ cells; PDI $=166.71 \mathrm{pg} / 10000$ cells; Figure $1 \mathrm{~b}$ ). There was no difference however in the total quantity of $\alpha$-casein between the treatments (Figure 1a). The predominant direction of secretion was different for the two proteins.

\section{DISCUSSION}

The primary aim of this experiment was to establish improved methodology for studying mammary development and lactation. Cell culture insert methodology demonstrated major advantages over three-dimensional culture methodology, namely no retention of milk proteins in luminal structures. However, we did not find the near absolute apical secretion of milk proteins or the quantity of $\alpha$-casein secretion, reported by Delabarre et al. (1997). Our results may be due to the presence of differentiation media in both apical and basal chambers resulting in the absence of a biochemical gradient across the cells.

It is widely accepted that the expression of milk protein genes in vitro is dependent on the presence of prolactin (German and Barash, 2002) and an association between MEC and laminin via cell surface integrins. However, in common with others (Yano et al., unpublished), we have observed that mammary specific function is possible on collagen I matrices when prolactin is omitted. Our results raise the issue of whether either laminin or prolactin is essential for mammary specific function in vitro.

The complete absence of laminin in our culture system is not certain however, as it has been shown that murine MEC have the ability to deposit laminin following adhesion to culture inserts (Strange et al., 1991). In contrast, other workers have concluded that the deposition of laminin and other ECM proteins is a function of the stromal cells (Haslam and Woodward, 2003), which are absent from our cultures.

The complete absence of prolactin or other hormones with affinity for prolactin receptors in control cultures is also not certain, as all media contained FBS. Undoubtedly, FBS contains an undefined milieu of growth factors and hormones. In support of this hypothesis, results from unpublished work at our laboratory have shown that removal of FBS from the culture system results in a decrease in the synthesis of $\alpha$-lactalbumin, but not its complete abolishment. Despite our results, numerous studies have shown that prolactin is essential for the expression of milk protein genes (Talhouk et al., 1993). However, the stage of lactation at which the cells are obtained may also have an effect on prolactin responsiveness.

\section{CONCLUSIONS}

This experiment has shown that collagen I is sufficient for milk protein gene expression, possibly due to the potential of MEC to deposit components of the 
basement membrane. In addition, we have demonstrated that cell culture insert methodology offers a practical alternative to a three-dimensional culture system based on a reconstituted basement membrane, and possibly that $\alpha$-lactalbumin as opposed to $\alpha$-casein offers a more accurate measure of functional differentiation. Future research will concentrate on developing a culture system free of the potentially confounding FBS. In future we will also look at replacing differentiation media in the apical chamber with media that encourages a biochemical gradient and correct cell polarization. This experiment has highlighted some key issues that require addressing in order for this system to provide a representative model of the bovine mammary gland.

\section{REFERENCES}

Delabarre S., Claudon C., Laurent F., 1997. Influence of several extracellular matrix components in primary cultures of bovine mammary epithelial cells. Tissue Cell 29, 99-106

German T., Barash I., 2002. Characterisation of an epithelial cell line from bovine mammary gland. In vitro Cell. Dev. Biol.-Animal 38, 293-297

Haslam S.Z., Woodward T.L., 2003. Host microenvironment in breast cancer developmentEpithelial-cell-stromal-cell interactions and steroid hormone action in normal and cancerous mammary gland. Breast Cancer Res. 5, 208-215

McConochie H.R., Rose M.T., Haresign W., Davies B., 2004. Establishment, characterisation and mammary specific function of a bovine mammary epithelial cell clone cultured on reconstituted basement membrane. Proc. Brit. Soc. Anim. Sci., p. 178

Rose M.T., Aso H., Yonekura S., Komatsu T., Ozutsumi K., Obara Y., 2002. In vitro differentiation of a cloned bovine mammary epithelial cell. J. Dairy Res. 69 345-355

Strange R., Li F., Friis R.R., Reichmann E., Haenni B., Burri P.H., 1991. Mammary epithelial differentiation in vitro: Minimum requirements for a functional response to hormonal stimulation. Cell Growth Differ. 2, 549-559

Talhouk R.S., Neiswander R.L., Schanbacher F.L., 1993. Morphological and functional differentiation of cryopreserved lactating bovine mammary cells cultured on floating collagen gels. Tissue Cell 25, 799-816

Yano T., Aso H., Sakamoto K., Kobayashi Y., Hagino A., Katoh K., Obara Y., 2004. Laminin and collagen IV enhanced casein synthesis in bovine mammary epithelial cells. J. Anim. Feed Sci. 13, Suppl. 1, 579-582 